\title{
WISATAWAN FLASHPACKER: SEBUAH PENDEKATAN EPISTEMOLOGIS
}

\author{
Putu Diah Sastri Pitanatri \\ Politeknik Pariwisata Bali \\ Email: diahsastri@gmail.com
}

\begin{abstract}
This paper examines flashpacker as an area of research; which discusses the new phenomenon of the flashpacker originating it's term from "backpacker". In this review, a deeper analysis of the evolution and development is presented, charting the growth of the literature, focusing both chronology and epistemology. A framework for understanding and creating knowledge about flashpacker is presented, forming the basis which signposts established research themes and concepts and outlines some future directions for research. In addition, this article focuses on constraining and propelling forces, ontological advances, contributions from key journals, emerging themes and issues. The paper suggests that flashpacker has numerous foundational origins that have complicated its growth as a viable and valued concept. This paper also proposes a number of research activities in understanding the flashpacker.
\end{abstract}

Keywords: flashpacker, epistemology, framework, creating knowledge, research activities

\section{Pendahuluan}

Terminologi flashpacker sebenarnya masih tergolong baru di kalangan akademisi pariwisata. Flashpacker sendiri baru mulai dikaji oleh akademisi sekitar tahun 2000-an seperti Hannam \& Diekmann (2010), Paris (2012), Butler \& Hannam (2014) serta Rosenberg, 2019). Dari beberapa kajian tersebut, disebutkan bahwa pada dasarnya, flashpacker merupakan backpacker yang "berevolusi" di dalam melakukan perjalanan. Jika beberapa dekade yang lalu seorang backpacker masih memiliki budget perjalanan yang rendah, maka masa ini ada kemungkinan ia memiliki pekerjaan baru yang memberikan tingkat kesejahteraan yang lebih tinggi dari sebelumnya. Hal ini berarti perilaku perjalanan yang dulu sangat "budgeted" sekarang memiliki daya beli yang 
lebih baik. Hyper-mobility, the career break phenomenon, dan kebutuhan untuk menyeimbangkan kehidupan pekerjaan memiliki kontribusi terhadap evolusi flashpacker (Hannam dan Diekmann, 2010).

Istilah "flash" sebenarnya merupakan sinonim dari 'style', dan flashpacking seberanrnya juga dapat diartikan sebagai travelling with style (Hannam \& Diekmann, 2010). Online dictionary mendefinisikan flashpacker sebagai backpacker dengan pendapatan yang yang lebih tinggi (Dictionary.com, 2019). Dalam perspektif lain, ada juga terminology yang menyebut flashpacker sebagai 'upscaled travel' dan 'Business-class backpacking' seperti yang disebutkan oleh Travelblogs.com (2009). Selain itu disebutkan juga flashpacker sebagai 'backpacking with bucks and toys' atau 'technotraveling", karena teknologi memerankan peran yang substansial bagi para backpacker ini (Flashpack.com, 2019). Secara singkat, flashpacker memiliki anggaran perjalanan yang lebih besar namun waktu yang lebih terbatas dibandingkan backpacker.

Adanya perkembangan teknologi yang kini lazim disebut sebagai industri 4.0 menjadikan tren perjalanan menjadi sebuah kebutuhan yang secara implisit menimbulkan perubahan demografis seperti rata-rata usia yang lebih tua untuk menikah, memiliki anak dan alokasi waktu untuk melakukan kegiatan perjalanan untuk berwisata yang semakin banyak (Hannam \& Diekmann, 2010). Flashpacker saat ini dikenal mendominasi kegiatan perjalanan di dunia dan merupakan tipelogi wisatawan yang menjadi alasan utama besarnya perubahan demografis masyarakat dan pertumbuhan yang pesat di teknologi informasi.

Di Indonesia, cukup banyak website dan blog yang mengulas flashpacker dalam perspektifnya masing-masing. Meskipun demikian, penelitian di Indonesia terkait fenomena ini masih sangat kering sehingga secara akademis fenomena ini masih miskin literatur. Apalagi tren berwisata telah menjadi fenomena global sehingga kajian seharusnya mulai merujuk pada consumer focused atau sering disebut sebagai 
post-fordist daripada penenakan lama yang merujuk pada product-led atau fordistmanner; yang memberikan kesempatan bagi bisnis yang bergerak di sektor pariwisata dapat merespon kebutuhan dan keinginan dari wisatawan (Page, 2009).

Seperti halnya backpacker, flashpaker memiliki motivasi utama melakukan perjalanan sebagi bentuk dari escapism, detachment, dan a sense of freedom (C. Noy, 2005; Chaim Noy, 2004; Reichel, Fuchs, \& Uriely, 2009) Escapism dalam konteks ini mengacu pada keinginan untuk menjauhkan diri dari tekanan psikologis, tuntutan, dan mengikis ritual kehidupan sehari-hari (Philip L Pearce, Murphy, \& Brymer, 2009), serta keinginan untuk "membebaskan diri" dari rutinitas keluarga, dari tekanan dari masyarakat Barat yang kompetitif, dan dari atmosfer politik-budaya di negara asalnya (Noy, 2004; Maoz, 2006, 2007) Sensasi detachment adalah kondisi yang diperlukan untuk mewujudkan motivasi tambahan melakukan perjalanan itu sendiri seperti relaksasi dan well-being (Reichel et al., 2009), pencarian pengalaman otentik (Murphy, 1997; Pearce et al., 2009), dan bahkan konstruksi temporal dari identitas baru (Desforges, 2000). Namun sebagaimana yang disebutkan pada awal artikel ini, kajian flashpacker masih sangat terbatas. Oleh sebab itu, sebelum fenomena ini dikaji lebih lanjut menjadi sangat penting untuk melihat landasan-landasan filosofis dari fenomena ini.

Artkel ini dibagi kedalam tiga bagian besar; pertama konseptualisasi terminology flashpacker yang kemudian dikembangkan dalam berbagai kajian literatur dan model pengembangan riset flashpacker. Pada bagian ini pendekatan epistemology dan ontologi dari flashpacker akan dibahas untuk menguraikan beberapa proposisi utama seputar terminologi flashpacker sehingga menyoroti pentingnya aspek ini dibahas dalam kajian-kajian pariwisata. Dari proposisi, konseptualisasi wisatawan flashpacker kemudian dibahas dari "perspektif pariwisata" yang melihat bagaimana terminology ini berkembang dari perspektif permintaan dan penawaran, menggunakan model sistem pariwisata (Flognfeldt, 2005). Bagian konseptual diakhiri dengan tinjauan singkat tentang tren utama dalam konteks 
kekuatan pendorong dan penghambat, dan ini membantu menjelaskan pertumbuhan fenomenal flashpacker yang secara distinctive membedakannya dengan wisatawan backpacker.

Bagian kedua dari tulisan ini kemudian meninjau flashpacker dalam literatur penelitian - melalui review dari jurnal-jurnal bereputasi dengan kemudian membuat ringkasan kronologis yang mengungkapkan asal-usul dan evolusi dari flashpacker dalam konteks pariwisata. Bagian ketiga mendeskripsikan evolusi wisatawan backpacker menjadi flashpacker. Dari kedua bagian ini dapat dilihat bahwa sampai saat ini tulisan dalam konteks akademis mengenai flashpacker masih sangat terbatas di Indonesia oleh sebab itu tulisan ini juga akan melihat bagaimana kajian tentang fenomena ini dapat menjadi pengembangan riset terbarukan dalam studi pariwisata di Indonesia. Flashpacker dapat menjadi ceruk penelitian baru diluar dominasi praksis dari penelitian-penelitian yang telah ada sebelumnya.

\section{Konseptualisasi Terminology Flashpacker}

Dari sudut pandang praksis profesional, atau industri, maka pertanyaan besarnya adalah nexus dari flashpacker. Apakah sebenarnya istilah ini layak untuk dijadikan sebuah studi ataukah istilah ini hanya sebuah "gimmick" yang sebenarnya tidak memiliki makna apa-apa dan sebutan lain dari backpacker saja. Pertanyaan ini kemudian merujuk pada pertanyaan selajutnya, apakah istilah ini memiliki body of knowledge yang kemudian layak untuk diteliti lebih lanjut? Secara ontologis, untuk menjawab pertanyaan ini dibutuhkan setidaknya identifikasi klaim yang jelas terhadap basis pengetahuan, konsep inti (core concept) dan identifikasi terminology yang nantinya dapat mengarah pada kesimpulan bahwa wisatawan flashpacker memang merupakan bagian dari sub bidang tipologi wisatawan - yang memiliki ciriciri berbeda dari wisatawan backpacker. Analisis ontologis yang dipergunakan dalam penyusunan makalah ini relatif berbeda dari pertimbangan epistemologis di mana 
makalah ini memeriksa disiplin dasar tipologi wisatawan dari teori dan metodologi yang dipergunakan.

Serangkaian proposisi inti dilakukan sebagai refleksi atas fenomena yang dapat diamati dalam kajian literature kemudian membentuk wacana flashpacker. Proposisi dan terminology backpacker sebenarnya sudah well established dalam literatur, dengan banyak dukungan penelitian, tetapi teori-teori flashpacker masih bersifat prediktif atau penjelasan. Dapat dipahami lebih lanjut bahwa sebenarnya fenomena ini masih dalam tahap pengembangan teori dan dapat dengan mudah diubah menjadi hipotesis untuk pengujian. Misalnya, walaupun jelas bahwa wisatawan di seluruh dunia, dengan pola mobilitas yang tinggi, lebih mengarah pada pola flashpacking daripada backpacking, namun samapai saat ini peneliti masih sangat sulit untuk memprediksi secara spesifik mana wisatawan flashpacker. Dalam tulisan Getz (2008) serta Getz dan Page (2014), terdapat beberapa tipologi wisatawan yang menurutnya shaping the future of tourism. Secara garis besar, tipologi wisatawan ini disajikan pada tabel 1 berikut ini.

Tabel 1. Tren Wisatawan Dunia

\section{Istilah Deskripsi}

Everyday Tipologi yang merayakan hal-hal kecil dalam kehidupan sehari-hari exceptional sebagai "extraordinary and exceptional events".

Misalnya: merayakan kehamilan dengan baby shower di luar kota.

Magic Fokus untuk mengingat kembali masa lalu yang dianggap memiliki nostalgia kenangan yang indah.

Misalnya: merayakan kembali pertemuan saat kuliah di luar negeri. Perjalanan dilakukan untuk mengingat kembali masa itu.

Leisure Kegiatan perjalanan yang diikuti dengan selebrasi dengan upgrade mengundang teman (yang mungkin baru ditemui di destinasi). Selebrasi bersifat spontan dan dianggap sebagai bagian dari sebuah pengalaman. 


\section{Istilah Deskripsi}

Mobile living Semakin mudahnya bepergian akan memunculkan istilah "the global nomad" dimana kemajuan teknologi serta aksesabilitas memungkinkan seseorang hidup dengan cara berpindah-pindah dari satu negara ke negara yang lain.

Performative Semakin tingginya partisipasi orang merayakan keterlibatan mereka leisure dalam sebuah kegiatan, kebahagiaan maupun berbagi pengalaman melalui media sosial dan teknologi seluler

Misalnya melalui status update dan live feed di media sosial

Authentic Wisatawan mencari pengalaman yang lebih otentik, dan salah satu experience cara untuk menemukan itu sering kali dilakukan melalui co-creation

Affluence Wisatawan menjadi semakin semakin demanding dalam bentuk kepemenuhan kebutuhan mereka dalam lingkup konsumsi di spektrum the experience economy

Consuming Wisatawan mulai memperhatikan isu-isu keberlanjutan (terutama with ethics lingkungan) dan melihat carbon footprint yang mereka tinggalkan dalah kehidupan sehari-hari. Hal ini berpotensi untuk mengubah leisure consumption di masa yang akan datang

Sumber: Dikembangkan dari (Yeoman, 2013) dalam (Getz, 2008)

Wacana ini kemudian merujuk dengan peristiwa dan pariwisata serta pemetaan ontologis studi backpacker yang telah dibahas oleh (G. Butler \& Hannam, 2014; Dayour, Kimbu, \& Park, 2017; O’ Regan, 2018). Dalam makalah tersebut telah dipaparkan berbagai pertimbangan untuk kontribusi teoretis dan landasan metodologis dari berbagai disiplin, yang kemudian berimplikasi pada fenomena wisatawan flashpacker. Dari penelitian tersebut kemudian mengarah pada evolusi studi tipologi wisatawan sebagai bentuk pengembangan lmu social yang melewati serangkaian fase pertumbuhan seperti yang akan disorot dalam bagian 3 nanti.

Apa yang digambarkan pada Gambar 1 dibawah ini adalah pemetaan bibliometric yang diambil dengan melakukan analisis terhadap 3,047 artikel tentang tourist di Scopus dengan menggabungkan 539 artikel yang khusus membicarakan 
tentang backpacker, new-bacpacker (neo-backpacker), flashpacker dan flashpacking. Dapat dilihat bahwa spectrum untuk penelitian flashpacker dan flashpacking masih sangat sedikit dibahas dalam kajian-kajian ilmiah sehingga menjadi ruang baru bagi peneliti pariwisata. Terlihat juga pada gambar dibawah ini spectrum publikasi (berwarna kuning) kedepannya akan menjadi kajian riset pariwisata yang memiliki tingkat kebaruan dalam studi mengenai wisatawan.

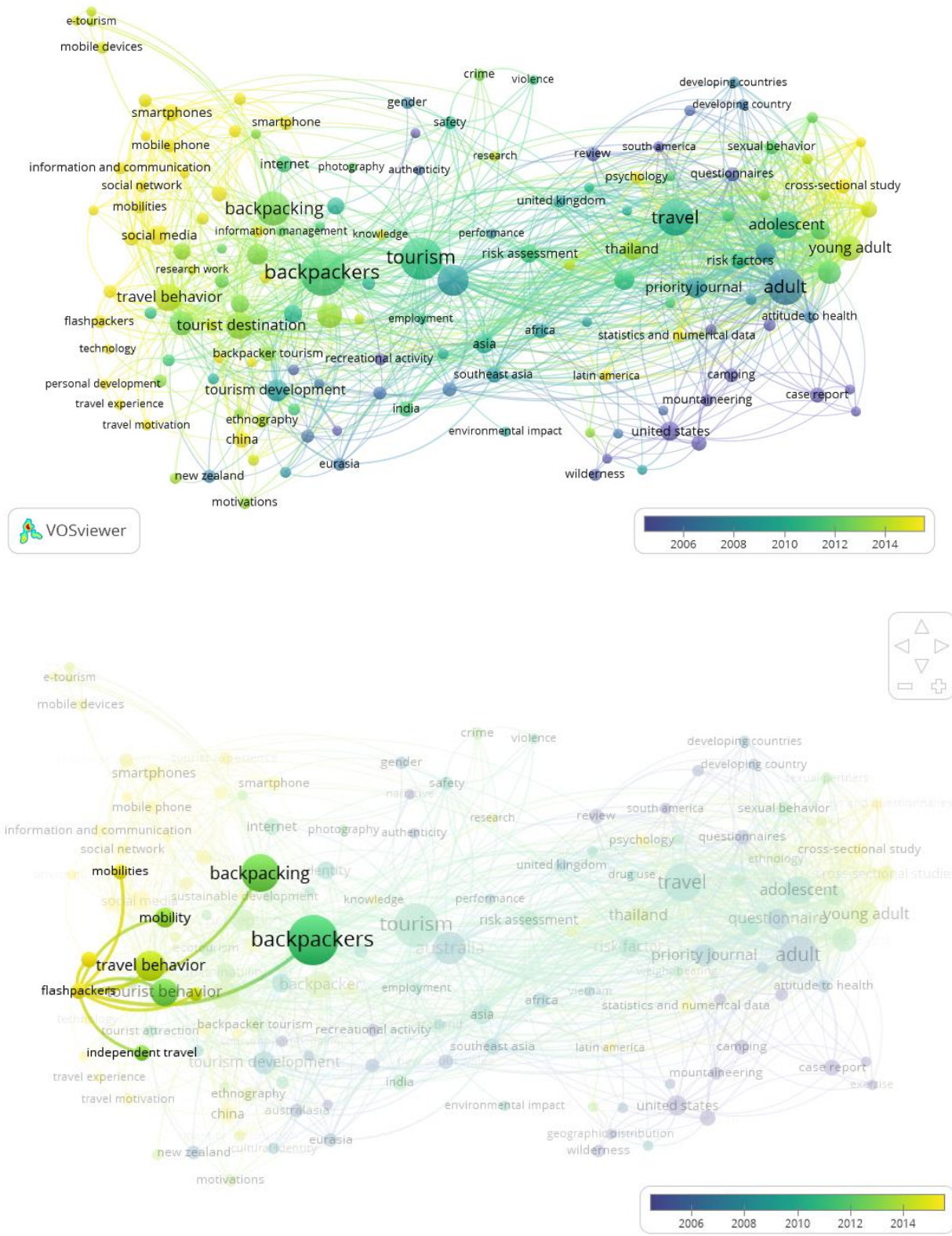

Gambar 1. Pemetaan Ontologis Flashpacker melalui bibliometric Sumber: Data Primer, 2020 
Perspektif yang lebih luas dari flashpacker dapat dilihat sebagai bagian dari studi tipologi wisatawan ditempatkan sebagai blok dasar untuk studi ini. Hal ini menunjukkan mengapa penjelajahan nexus studi flashpacker dengan tipologi wisatawan memiliki relevansi yang cukup besar karena telah menjadi paradigma yang lebih merangkul semua tempat pariwisata itu berada. Dimensi waktu luang diilustrasikan oleh Page dan Connell (2010) di mana konsep yang berkontribusi dan fokus yang mendasarinya adalah pada hiburan (entertainment), pola konsumsi (consumption) dan keinginan (desire) untuk mendatangi sebuah destinasi. Ketiga hal ini menjadi landasan yang kemudian membedakan tipologi wisatawan satu dengan yang lainnya. Flashpackers umumnya masyarakat urban dengan mobilitas tinggi dengan'kultur traveling' yang muncul dari kalangan backpacker. Flashpacker bisa disebut sebagai individu hypermobile yang secara fisik dan virtual melekat dengan kultur backpacker dan hidup dalam proses penyatuan yang berlangsung antara teknologi digital dan kehidupan sehari-hari. Flashpacker adalah perintis awal yang mengadopsi, mengeksplorasi dan menciptakan ruang virtual dari backpacking (Paris, 2012).

Pernyataan diatas jelas menekankan adanya keterlekatan antar teknologi digital dengan mobilitas dikalangan flashpacker. Selanjutnya, Paris mencoba membandingkan kultur perjalanan antara flashpacker dengan kelompok traveler yang disebutnya 'non-flashpacker' (backpacker). Analisis konsensus kultural digunakan untuk melihat perbedaan keduanya. Survei dilakukan secara online di sebuah grup Facebook backpacker dan offline di sebuah motel di Australia. Penelitian Paris, menyebutkan bahwa preferensi dan intensitas penggunaan gadget ketika traveling digunakan sebagai instrumen survei untuk membentuk 2 kelompok besar yaitu flashpacker dan non-flashpacker (conventional backpacker). Flashpacker sangat gadget oriented sementara backpacker justru ingin lepas dari gadget dan dunia modern. Temuan ini, kemudian menjadi dasar dalam memahami flashpacker dalam spectrum yang sedikit berbeda dari backpacker konvensional. 
Istilah 'wisatawan flashpacker' sebelum ini memang tidak banyak digunakan, sebelum tahun 2013 sebelum ITB Berlin World Travel Trends Report melaporkannya sebagai the new niche-market in tourism. Sebelumnya Pearce (2012) mengembangkan kerangka kerja untuk perencanaan untuk lebih memahami perkembangan dari wisatawan backpacker. Sebelum itu, diskursus antara perbedaan backpacker dan flashpacker masih terus mendominasi diskusi. Oleh karena itu, tahun 2013 dapat dikatakan menjadi suatu titik balik dalam pengakuan istilah 'flashpacker', yang secara umum diakui sebagai inklusif dari wisatawan backpacker dalam pendekatan terpadu dan telah menjadi bagian dari pengembangan dan pemasaran wisatawan.

Seperti halnya semua bentuk perjalanan dengan minat khusus, flashpacker dapat dilihat dalam perspektif permintaan dan penawaran. Konteks ini mengacu pada pengalaman wisatawan yang termotivasi oleh minat khusus (Ryan et all, 2003) dan bukan apa yang ditawarkan melalui produk. Definisi ini menunjukkan bahwa kegiatan perjalanan yang dilakukan oleh flashpacker relative bersifat motivasi intrinsic atau berasal dari dalam.

\section{Flashpacker Dalam Kajian Literatur}

Istilah backpacker secara akademis baru di bahas pertama kali oleh peneliti asal Australia, Philip Pearce pada tahun 1990 dalam makalah yang berjudul "The Backpacker Phenomenon: Preliminary Answers to Basic Questions". Dalam makalahnya Pearce mengembangkan kriteria untuk membedakan backpackers dari wisatawan lain. Dijelaskan para backpacker adalah wisatawan yang lebih memilih akomodasi hemat, seperti bertemu penduduk lokal dan wisatawan lain, pola perjalanan yang independen, memiliki jadwal perjalanan yang fleksibel, bersifat informal, cenderung menyukai kegiatan partisipatif dan memiliki liburan yang relative lebih lama dari wisatawan konvensional. 
Penelitian selanjutnya (Hing, Mccabe, Lewis, \& Leiper, 1998; Richards \& Wilson, 2004; Cave, Thyne, \& Ryan, 2007; O’Reilly, 2006; Pearce et al., 2009; Uriely, 2009; Bosangit, Hibbert, \& McCabe, 2015; Luo, Huang, \& Brown, 2015; G. Richards, 2015) mendokumentasikan karakteristik backpackers yang menjelaskan mereka sebagai wisatawan yang bepergian tanpa rencana, 'budgeted', menggunakan transportasi umum, mencari pengalaman otentik, menghindari 'tourist bubble' dan tidak berhasrat mencari kenyamanan. Oleh karena itu backpacker telah diidentifikasi dengan tepat sebagai turis dengan kharakteristik khusus (Prebensen, 2017). Fenomena backpacker sebagai metafora dari mobilitas dalam konteks modern merupakan jalan hidup dan perjalanan, sekaligus merupakan ekspresi identitas (Pitaya et all, 2019). Hal ini berarti backpacker merupakan metafora dari pariwisata modern dan generasi muda modern.

Dalam lingkup penelitian yang terpublikasi dalam Scopus, dapat dilihat bahwa penelitian terkait backpacker telah dilakukan sejak tahun 1972 oleh penelitipeneliti dunia seperti Butler, Pearce, Paris, dan sebagainya. Meskipun demikian baru setelah tahun 2010, penelitian terkait flashpacker dikembangkan sebagai sebuah studi baru dari backpacker. 

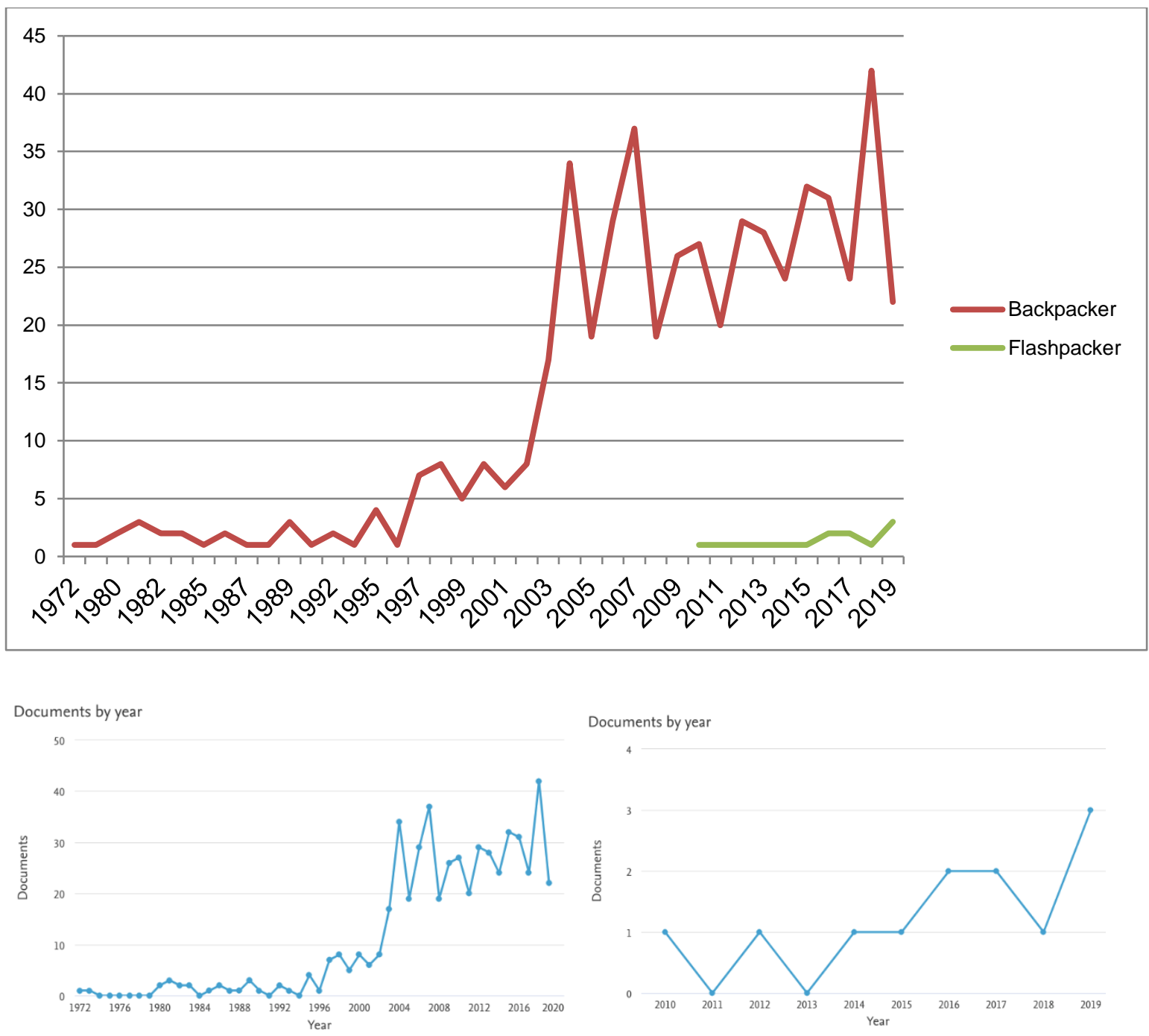

Gambar 2. Perbandingan Publikasi Backpacker dengan Flashpacker dalam Scopus Sumber: Data Primer, 2019

Dari gambar 2 diatas dapat dllihat bahwa tren publikasi penelitian tentang backpacker sangat fluktatif, namun pada tahun 2019 tampak terjadi penurunan publikasi dengan topic backpacker. Sebaliknya, meskipun relatif baru, tren flashpacker dalam kaidah akademis terlihat mengalami peningkatan dari tahun ke tahun. Hal ini, menunjukkan ada ketertarikan peneliti untuk melihat fenomena ini sebagai gap baru dalam riset yang dapat diekplorasi lebih lanjut. 
Seiring perkembangan, backpacker mengalami evolusi menjadi flashpacker, sebagai terminology baru dalam kosa kata pariwisata untuk menggambarkan backpackers yang berkelas atau yang sebut sebagai 'Hilton Hippies'. Lebih lanjut konsep flashpacker oleh Bleach dan Schofield (2004) disebutkan tentang wisatawan mandiri dengan kharakteristik seperti backpacker akan tetapi tidak keberatan untuk membayar barang dan jasa di destinasi dengan harga tinggi, sangat stylist dan modis (mengedepankan mode dan gaya perjalanan), serta memiliki pemanfaatan maksimal terhadap teknologi digital (gadjet).

Konsep tersebut disebut Cochrane (2005) sebagai konsep "neo backpacker" yaitu wisatawan mandiri yang memiliki tingkat kesejahteraan berlebih, mereka yang melakukan perjalanan wisatanya secara individual, independen akan tetapi tidak selalu bergantung pada pembiayaan yang rendah terhadap barang dan jasa selama berwisata. Zhang, Tucker, Morrison, \& Wu, (2017) lebih lanjut mencirikan flashpacker sebagai backpacker yang technology aided, cepat, memiliki budget perjalanan yang relative tinggi, kombinasi dari low cost dan luxury travel serta memiliki kebebasan untuk menggunakan uangnya untuk alasan kenyamanan.

Perkembangan backpacker ke flashpacker dikreditkan ke perubahan sosial ekonomi dan adanya pertumbuhan teknologi informasi dan komunikasi - yang telah secara signifikan mempengaruhi gaya hidup konsumen dari wisatawan modern (Buhalis \& Law, 2008; Gretzel, et all, 2015; Mistilis, Buhalis, \& Gretzel, 2014; Xiang, Magnini, \& Fesenmaier, 2015; Xiang, Wang, O’Leary, \& Fesenmaier, 2015; Wang, Xiang, \& Fesenmaier, 2016). Implikasi dari perkembangan teknologi ini memicu spekulasi bahwa selain modernitas, hal ini mungkin merupakan kristalisasi dari 'digital divide' (Cheng, 2016; Minghetti \& Buhalis, 2010) antara backpacker tradisional dan kontemporer, yang telah bertanggung jawab untuk menciptakan perbedaan di antara keduanya. Bagi backpacker kontemporer (flashpacker), kegiatan perjalanan harus dilengkapi dengan gadget, kamera digital dan perlengkapan teknologi lainnya termasuk utilitas multiguna yang dapat memfasilitasi perjalanan (Paris, 2012). Lebih 
lanjut Paris menyebutkan bahwa terdapat 'kebutuhan' backpacker kontemporer untuk terhubung secara virtual ke dunia luar 24/7.

Oleh karena itu backpacker maupun flashpacker diakui 'berbeda' dari turis konvensional yang cenderung "mass' (Morrison, et all, 1996; Uriely, et all, 2002; Pearce, 2006), dan bertentangan dengan terminology (Plog, 1974) yang disebutnya sebagai psychocentrics' atau dependables dimana dalam karakteristik tersebut, turis bepergian ke destinasi untuk 'mencari kenyamanan dan 'feels like home'. Gaya turis ini kemudian dikenal sebagai istilah 'tourist bubble' yaitu turis yang pergi ke destinasi baru tapi tidak ingin lepas dari atribut destinasi asalnya. Misalnya turis Eropa yang hanya mau menginap di hotel standar 'Eropa', makan makanan di restoran Prancis atau Itali dan naik maskapai Eropa. Gaya perjalanan dan perilaku backpacker maupun flashpacker sangat jauh dari karakteristik tersebut. Sehingga kemudian telah membangkitkan rasa ingin tahu para peneliti pariwisata selama lebih dari dua dekade.

\section{Evolusi Backpacker Ke Flashpacker}

Jika merujuk pada penelitian yang dilakukan oleh Pitaya (2019), disebutkan bahwa catatan sejarah menunjukkan bahwa istilah backpacking travel atau perjalanan dengan memanfaatkan tas atau wadah yang ditempatkan di punggung sebenarnya telah ada sejak ribuan tahun yang lalu. Penemuan mumi “Ötzi the Iceman.” oleh dua orang backpacker asal Jerman; Helmut dan Erika Simon di Ötztal pegunungan Alpen pada tahun 1991 menunjukkan bukti konkrit bahwa suku nomaden di jaman pra sejarah telah menggunakan ransel primitive. Penelitian para ahli menunjukkan bahwa Otzi hidup sekitar 3400 atau 3100 tahun sebelum masehi. Dengan penemuan mumi beserta perlengkapan perjalanannya tersebut maka Ötzi sering disebut sebagai backpacker pertama di muka bumi (Pitaya et al., 2019). 
Sebenarnya, dalam konteks perjalanan manusia, penjelajahan dunia pertama yang tercatat dalam sejarah adalah perjalanan yang dilakukan oleh Antipatros Sidonius, Philo Mechanicus, Strabo Herodotus dan Diodorus Sicilius sekitar abad ke 2 sebelum Masehi. Perjalanan dan pengalaman mereka tertuang dalam antologi puisi yang mengisahkan tentang 7 keajaiban dunia pada masa itu. Selain itu ada perjalanan pendeta Budha, I Cing yang berkelana menuju India untuk mendapatkan kitab suci hingga pengembaraannya menuju Sriwijaya dan Jawa pada sekitar abad ke 7 Masehi. Tercatat perjalanan Marco Polo dari Italia ke Cina melalui Jalur Sutera pada abad ke 13 sebagai implementasi dogma Gold, Gospel dan Glory. Selain itu terdapat perjalanan Christopher Columbus pada tahun 1496 yang diikuti oleh Amerigo Vespucci pada tahun 1503 dalam menemukan gugusan benua Amerika.

Namun jika merujuk kembali ke terminologi pariwisata yang tujuan melakukan perjalanan untuk kebutuhan rekreasi dan bersenang-senang, maka momentum backpacker sebenarnya dimulai setelah abad ke 17; yaitu ketika era conquistadores (para penakluk) berakhir. Sekurang-kurangnya terdapat tujuh momentum evolusi backpacker menjadi flashpacker sebagaimana tampak pada gambar 3 dibawah.

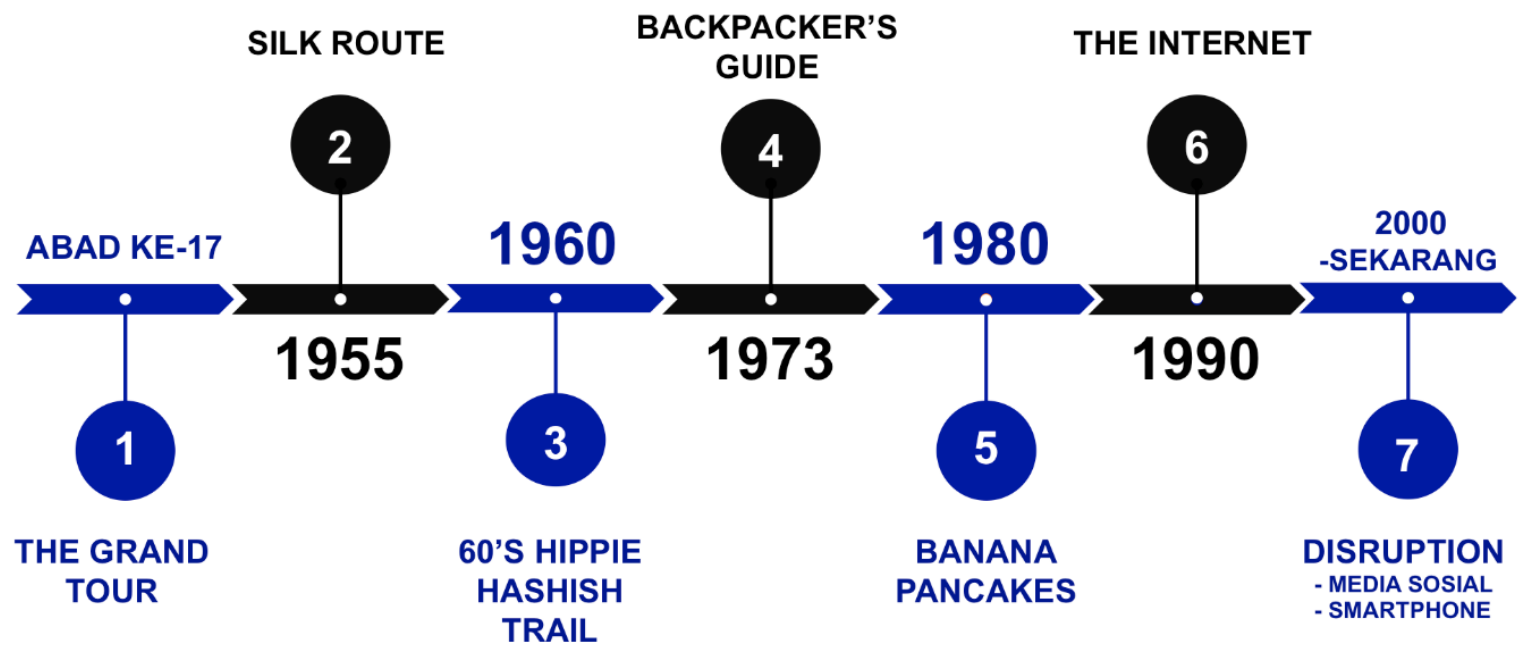

Gambar 3. Momentum Evolusi Backpacker ke Flashpacker Ilustrasi Penulis terhadap Kajian Literatur, 2020 


\section{a) The Grand Tour}

Sebelum abad ke-17 dan ke-18, selain tujuan untuk gold, gospel dan glory, gagasan bepergian (traveling) dianggap sebagai tindakan negatif. Hal tersebut dikarenakan saat seseorang bepergian, kemungkinannya ia melarikan diri dari peperangan, karena menderita penyakit atau terjadi tragedi yang mengharuskannya untuk pergi. Setelah abad ke 17, terjadi momentum kegiatan pariwisata yang merupakan awal orang melakukan perjalanan sebagai bentuk dari pendidikan dan rekreasi. Perjalanan ini dikenal dengan istilah Grand Tour.

Pada saat itu banyak pelajar dari kelas atas yang merupakan putra dan putri Aristokrat Inggris bepergian ke Eropa sebagai bagian dari pengembangan karir dan kebutuhan pendidikan mereka (Sroypetch, 2016). Selain itu grand tour juga dilakukan oleh pria Eropa kaya dari abad ke-17 sebagai kegiatan tur akbar ke negara-negara sekitarnya sebelum akhirnya menikah.

Jika merujuk ke asal kata, terminologi Grand Tour sebenarnya diperkenalkan oleh Richard Lassels melalui publikasinya yang berjudul The Voyage of Italy pada tahun 1670. Lassels yang merupakan seorang travel writer pada masanya turut mempopulerkan istilah ini. Pada masa itu Grand Tour begitu populer di kalangan para pemuda bangsawan Eropa, sehingga dianggap sebagai salah satu inisiasi menuju proses kedewasaan. 


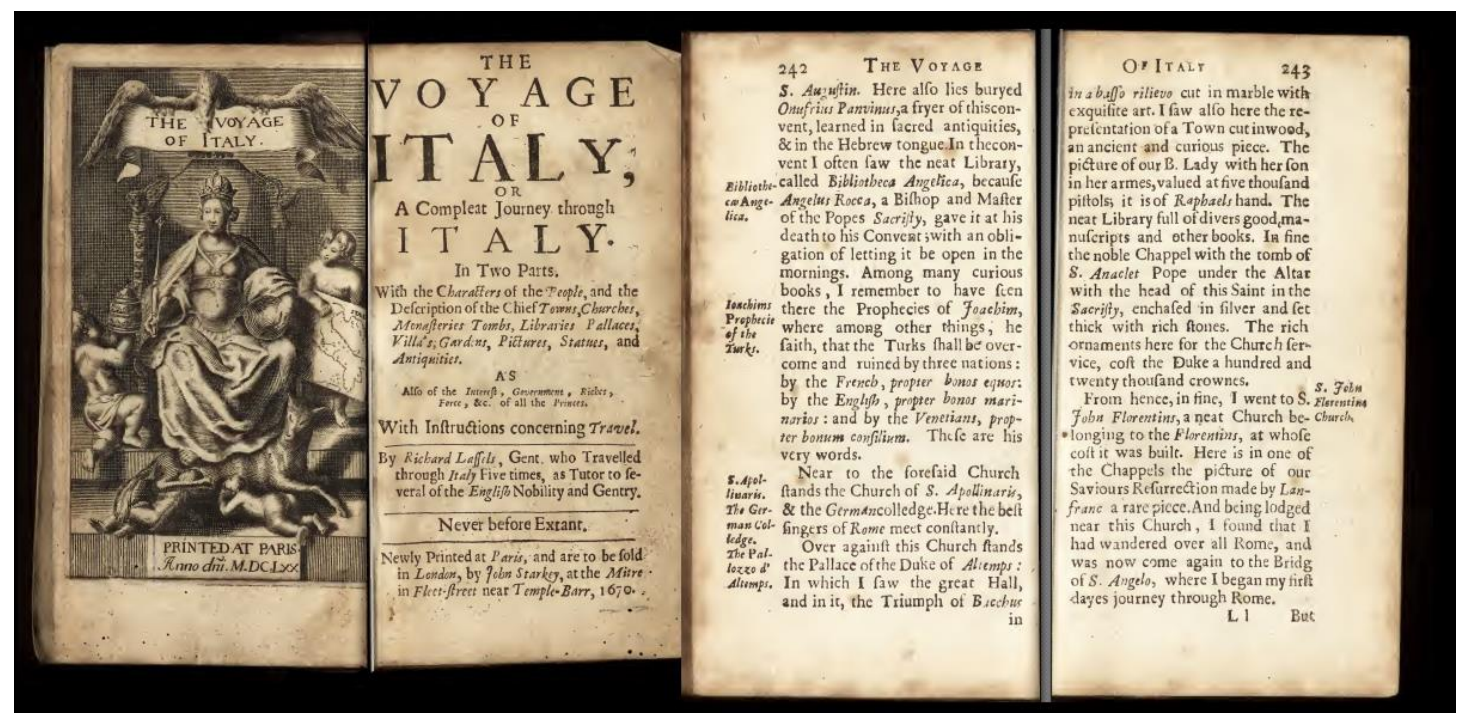

Gambar 4. Buku The Voyage of Italy karya Richard Lassels

Sumber: Koleksi Biblioteca Angelica (Perpustakaan Angelica), fondata nel 1604 dal vescovo agostiniano Angelo Rocca, Roma.

Dalamperkembangan selanjutnya, tidak hanya kaum bangsawan saja yang melakukannya, tetapi juga para pemuda penganut protestan dari wilayah Eropa Utara dan Skandinavia turut meramaikan kegiatan wisata ini. Bahkan di awal abad ke 19 banyak para backpacker dari Amerika Serikat datang ke Eropa untuk merasakan pengalaman baru dalam perjalanan Grand Tour. Karakter Grand Tour yang pada awalnya khas bangsawan lambat laun menjadi lebih merakyat sampai akhirnya perjalanan ini menjadi sangat populer dan umum dilakukan oleh masyarakat kebanyakan.

\section{b) Silk Route (1955)}

Pada tahun 1955, sekelompok mahasiswa Universitas Inggris memulai ekspedisi darat untuk mengikuti jejak jejak oleh Marco Polo "the silk road" yang menghubungkan jalur Timur ke Barat. Para siswa mendokumentasikan perjalanan mereka dan kata "overland" waktu itu membuat banyak orang-orang muda Barat penasaran. Silk route inilah yang selanjutnya memicu awal Jalur Hippie. 
Silk Route, atau dikenal sebagai 'Jalan Sutra (silk road)', berasal dari kata "Seidenstraße" yang diperkenalkan oleh ahli geografi Jerman bernama Ferdinand von Richthofen pada akhir abad ke-19 (Warwick, 2016). Meskipun saat itu tujuan awalnya adalah untuk militer, implikasi terpenting dari rute perdaganga ini adalah komunikasi dan diplomasi. Hal ini disebabkan ada hubungan yang luas di hampir seluruh benua Asia, Mediterania, dan kemudian meluas ke Afrika Utara dan Timur Laut serta Eropa. Jalur Sutra tidak hanya rute perdagangan paling terkenal dari peradaban Tiongkok kuno, tetapi juga awal mula Cina membuka negaranya pada dunia.

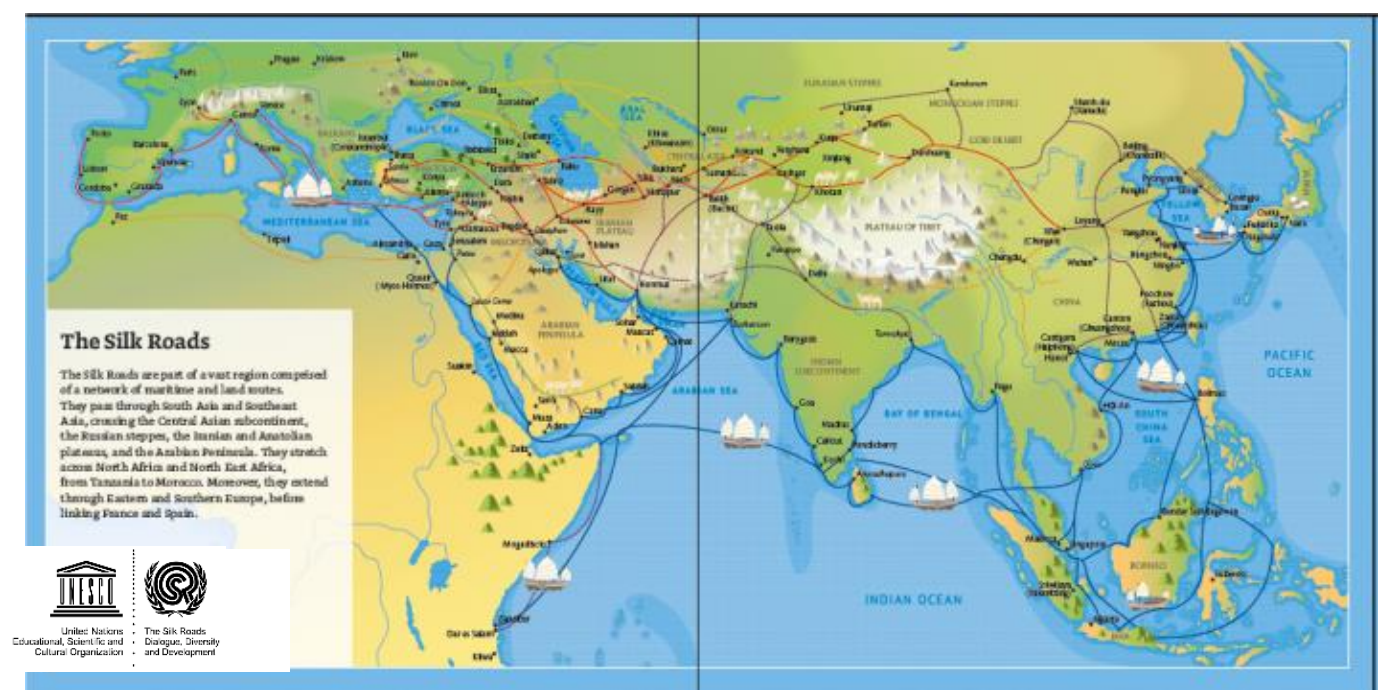

Gambar 5. Silk Road / Silk Route Sumber: UNESCO, 2019

Salah satu peran terpenting dari silk route adalah membawa budaya dan orangorang dalam kontak satu sama lain. Pada tataran praktis, para pedagang harus mempelajari bahasa dan kebiasaan negara-negara yang mereka lalui, agar berhasil bernegosiasi. Interaksi budaya adalah aspek penting dari pertukaran materi. Selain itu, banyak wisatawan yang berkelana ke Jalur Sutra untuk mengambil bagian dalam proses pertukaran intelektual dan budaya ini yang terjadi di kota-kota di sepanjang rute. 
Later, social change and spatial reorganization has made the phenomenon of the Grand Tours transformed into the concepts of 'drifting', 'wandering', and 'tramping' around the 1950s

(Loker-Murphy \& Pearce, 1995)

Sebagaimana yang disebut oleh Loker-Murphy dan Pearce (1995) diatas, adanya perubahan social dan perkembangan spasial mentransformasi grand tour ke konsep 'drifting' (keluyuran), 'wandering'(petualangan), dan 'tramping' (pengembaraan) yang dilakukan melalui 'petualangan' melewati silk route.

Perkembangan selanjutnya, jalur penerbangan lintas Atlantik juga diperkenalkan dengan terbangnya pesawat De Havilland Comet dari British Overseas Airways Corporation (BOAC) pada tahun 1958. Penerbangan ini menghemat perjalanan dari London ke New York yang semula membutuhkan waktu 6 hari dengan kapal laut menjadi hanya 6 jam saja. Hal ini juga menjadi banyak anak muda yang termotivasi untuk melakukan kegiatan kegiatan perjalanan

\section{c) Sixties Hippie Hashish Trail (1960)}

Silk Route segera memicu kelahiran Jalur Hippie - atau rute yang membentang dari Eropa ke India. Ini adalah momen dalam sejarah ketika gagasan 'backpacking' benar-benar mulai muncul. Meskipun telah ada penerbangan, biaya perjalanan udara sangat tidak terjangkau oleh mahasiswa muda (Jo Blow). Hal inilah yang kemudian memacu gagasan bepergian melalui darat dengan transportasi lokal, jalan kaki (pedestrian walk), dan menumpang (hitchhacking). Perjalanan The Beatles pada tahun 1968 ke India semakin memicu keinginan untuk menjelajahi Timur. Pada waktu itu ganja sudah tersedia di Afghanistan, Kashmir dan Nepal dan sampai tahun 1973, masih legal untuk membeli ganja atau charas di warung lokal. 
Terminologi 'hippy' sebenarnya berasal dari kata hipster yang merupakan evolusi dari istilah 'beatnik' yang sempat populer di era 1950-an di Amerika. Kata "hip" dan "hep" berasal dari budaya Amerika, Afrika dan menunjukkan "kesadaran." Hippies mewarisi nilai-nilai countercultural dari Beat Generation yang kemudian menciptakan komunitas mereka sendiri, mendengarkan psychedelic rock, memeluk revolusi seksual dan dekat dengan ganja-sehingga seringkali dinggap sebagai orang aneh (freak). Pada saat itu, para 'hippies' sebagian besar merupakan orang asal Eropa, Jepang, Amerika, Kanada, Australia, dan Kiwi. Perjalanan biasanya akan dimulai dari kota-kota di Eropa barat, seringkali London, Kopenhagen, Berlin Barat, Paris, Amsterdam, atau Milan. Sebagian besar perjalanan melewati Istanbul, di mana rute kemudian dibagi. Rute utara biasanya melewati Teheran, Herat, Kandahar, Kabul, Peshawar dan Lahore menuju India, Nepal, dan Asia Tenggara. Perjalanan yang disebut sebagai hippies route tergambarkan pada gambar 6 berikut ini.

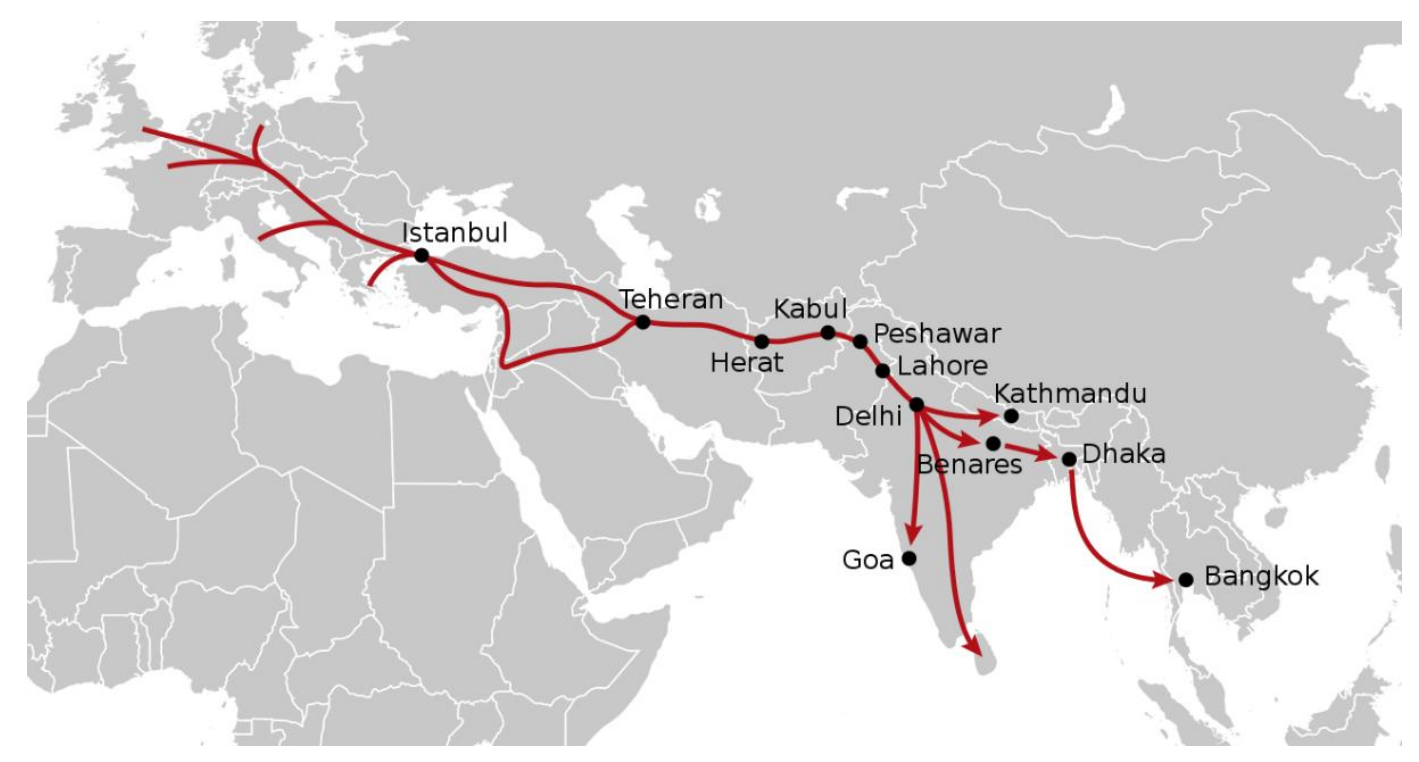

Gambar 6. Rute Hippies

Sumber: Karte NordNordWest, 2019 
Talks of paradise, beaches and legal drugs aroused the counterculture and youngsters eager to break away from the frameworks of society.

(Gregory, 2017)

Sebagaimana yang disebutkan diatas, surga, pantai dan narkoba legal merupakan tiga pencetus utama perjalanan backpacker ala hippies ini. Meskipun demikian jejak hippie klasik ini berakhir pada 1979, ketika revolusi Islam di Iran dan invasi Rusia ke Afghanistan menutup rute darat dari Eropa. Saat itu Libanon telah terjerumus ke dalam perang saudara sementara Chitral, Kashmir dan Nepal menjadi kurang menarik karena ketegangan militer di daerah tersebut.

\section{d) Backpacker's Guide: 1973.}

Momentum backpacker selanjutnya adalah diterbitkannya guide book The Lonely Planet pada tahun 1973 "Across Asia on the Cheap". Diterbitkannya guide book The Lonely Planet ini kemudian memotivasi para backpacker asal Eropa untuk memulai perjalanannya di benua Asia. Buku ini sebenarnya merupakan kisah perjalanan bulan madu Tony dan Maureen Wheeler dari London ke Australia, melintasi Eropa dan Asia - tanpa apa-apa selain beberapa dolar di saku mereka dan keinginan untuk berpetualang.

The Lonely Planet menjadi begitu populer sehingga membuat para pendirinya memutuskan untuk melakukan perjalanan dengan sepeda motor ke seluruh Asia Tenggara. Pada tahun 1975, The Lonely Planet mempublikasikan bukunya yang kedua dengan judul Across Asia on the Cheap: A Complete Guide to Making the Overland Trip. 

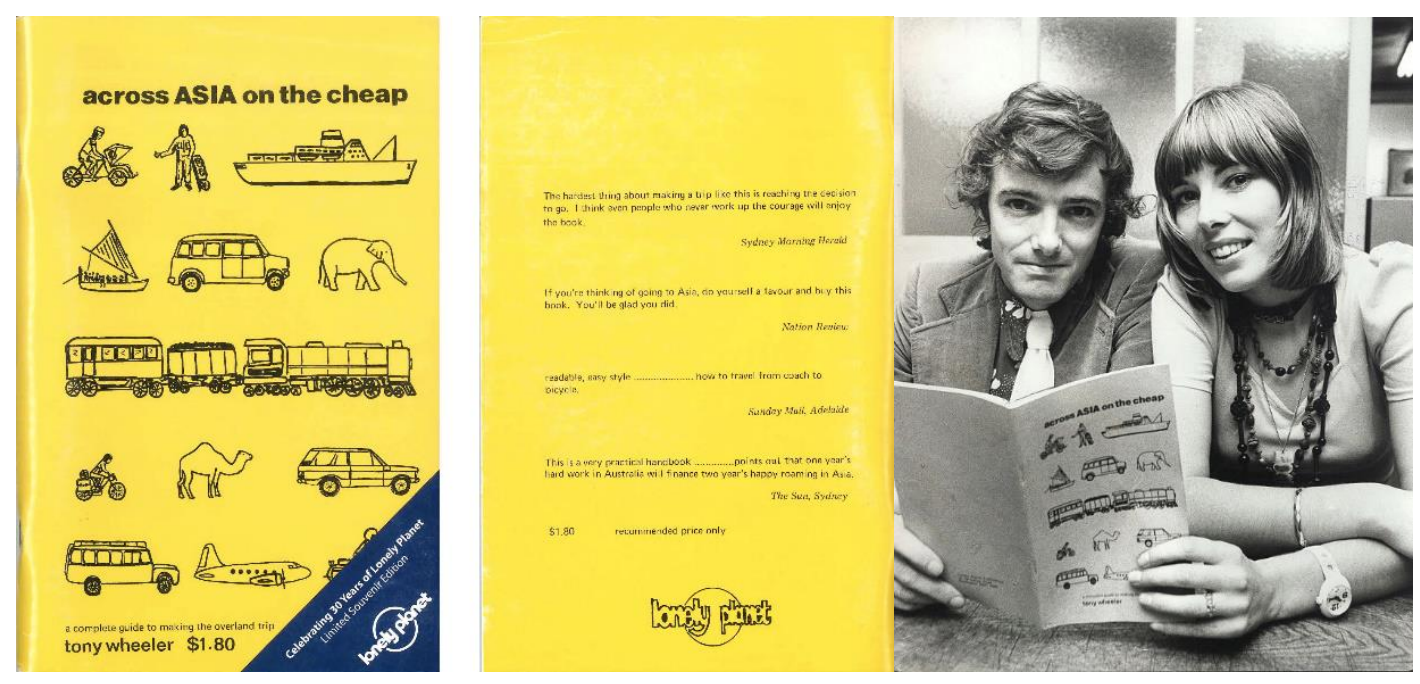

Gambar 7. Publikasi Pertama The Lonely Planet (kiri) dan Pendiri Lonely Planet, Tony dan Maureen Wheeler (kanan)

Sumber: The Lonely Planet, 2019

Saat masa ini, banyak warga Australia dan New Zealand mulai melakukan perjalanan menuju Nepal, India dan Thailand. Ketika Perang Vietnam berakhir pada tahun 1976, wilayah Asia Tenggara menjadi destinasi wisata baru bagi para backpacker Eropa dan Amerika dan kemudian menjadi momentum baru bagi perjalanan backpacker.

\section{e) Banana Pancakes}

Segera, pembicaraan tentang surga yang tak tersentuh di Asia Tenggara mendorong para pelancong untuk menjelajah di luar jalur hippie dan menjelajahi apa yang segera dikenal sebagai Jejak Banana Pancakes - yang tersebar di Thailand, Kamboja, Indonesia, Laos, dan seterusnya. Sebutan ini berasal dari makanan yang banyak dijajakan di jalan-jalan Indo China (Vietnam, Laos dan Kamboja). Banana Pancake sendiri berupa kue terbuat dari tepung dan buah pisang yang diberi topping beraneka macam sesuai dengan pilihan pembeli. 
Kue pisang ini mirip rasanya seperti banana pancake yang dengan mudah ditemui di Negara asal mereka - sehingga rasanya tidak asing di lidah. Apa yang kemudian populer dengan Banana Pancake Trail adalah rute yang tidak terlalu spesifik melalui Asia namun sangat populer bagi para backpacker dan long-term budget travelers.
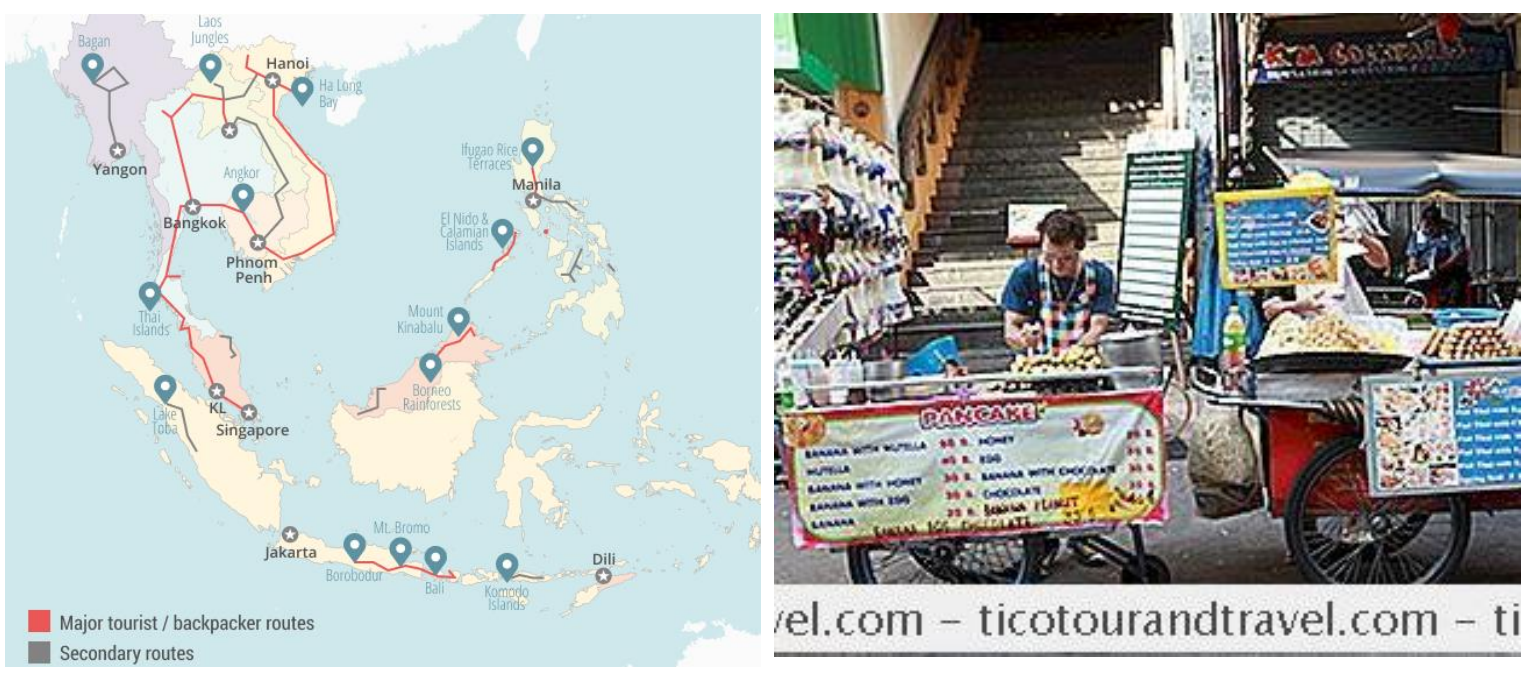

Gambar 8. Rute Banana Pancake (kiri) dan Penjaja banana pancake (kanan) Sumber: www.indietraveller.co, 2018

Meskipun konsep itu tidak pernah direncanakan dan tentu saja tidak resmi bagi wisatawan beranggaran terbatas dan backpacker biasanya berakhir melalui tujuan yang sama di Asia - terutama di Asia Tenggara dan Asia Selatan - saat mereka melakukan perjalanan melintasi benua. Wisatawan Backpacker tidak harus mengikuti rute atau arah yang sama di sepanjang Jalur Pancake Pisang, namun, seringkali para backpacker in bertemu dengan orang yang sama berulang kali selama perjalanan ini.

\section{f) Internet}

Setelah masa keemasan guide books, maka pada awal tahun 90an mulai berkembang internet. Di Indonesia sendiri, memang internet belum populer saat itu, namun di Eropa dan Amerika, World Wide Web (www) sudah dapat diakses 
oleh masayarakat luas, Internet menjadi kendaraan besar untuk komunikasi, berbagi tips, saran dan fakta perjalanan. Guide books mulai tersedia secara online dan mulai muncul istilah "blogger" bagi wisatawan yang melakukan perjalanan kemudian menuliskan perjalanannya dalam blog secara online.

Pada masa ini tingkat perencanaan relative lebih mudah dilakukan, bahkan sebelum meninggalkan negara asal. Sebagian besar backpacker membawa discman, kamera (dengan film roll isi 36) dan buku panduan. Dengan masuknya pengetahuan yang dapat diakses ini; orang-orang tidak terlalu khawatir dengan 'yang tidak diketahui' dan negara-negara baru, jalan setapak dan rute yang dibuka saat perjalanan di destinasi tersebut. World wide web juga akhirnya memacu pertumbuhan website traveling dan pada akhirnya memunculkan review secara online seperti TripAdvisor.

\section{g) Era Disrupsi (Disruption)}

Disrupsi memungkinkan seseorang melakukan kegiatan perjalanan di era digital yang tidak lepas dari intervensi teknologi digital. Fenomena ini muncul sejak semakin bergantungnya manusia dengan gadget. Tentu saat ini sangat sulit menemukan seorang traveler yang melakukan perjalanan tanpa membawa gadget. Tas backpack yang digendong atau koper yang dibawa kemana-mana kini berisi kebutuhan penting perjalanan yang tak hanya pakaian dan uang, tapi juga handphone, tablet, laptop, lengkap dengan charger, powerbank, atau bahkan kamera, tripod, dan selfie stick (tongsis). Flashpacker adalah tech-savvy backpacker yang muncul di era internet dan social media.

We carry a phone, an MP3 player, a guide book, a map, our money, our passport, our tickets and a world of knowledge in a smart phone.

(NomadsWorld, 2018) 
Flashpacker membawa telepon, pemutar MP3, buku panduan, peta, uang, paspor, tiket dan dunia pengetahuan di smartphone mereka. Hal ini sedikit tidak berimplikasi terhadap banyak perusahaan yang dulunya bergantung dari penjualan guide books, peta dan tur perjalanan. Salah satunya adalah travel agent tertua didunia; Thomas Cook yang berdiri pada tahun 1841; dinyatakan pailit pada September 2019 lalu.

Teknologi telah membuka jalan bagi Google Maps dan media social- yang memungkinkan mereka berkomunikasi hampir bebas dan seketika dengan sesama flashpacker lainnya dan teman di rumah. Hampir semuanya dapat dipesan sebelum kedatangan. Buku panduan dan peta sekarang menjadi 'tidak perlu' dan flashpacker bisa tiba di kota yang tidak dikenal. Jika beberapa decade dulu backpacker setidaknya harus berbekal pengetahuan tentang apa yang harus dilakukan dan apa yang harus dilihat, saat ini mereka dapat merencanakan rencana perjalanan bahkan saat sudah berada di destinasi tersebut hanya dengan menggunakan smartphone. Word of Mouth saat ini juga telah mengambil bentuk yang berbeda Social Media.

The hashtag of \#OOTD or 'Outfit of The Day' has become extremely popular in the social media. They would travel with more clothes and fashion items than the conventional style of backpacker who might be only wearing 2-3 t-shirts throughout the whole trip.

(Pitanatri \& Pitana, 2019)

Jika merujuk kembali pada terminology backpacker, istilah ini muncul dari sebutan wujud fisik berupa tas gendong 'backpack', kemudian berkembang melahirkan istilah kultural yang kini identik dengan traveler, pelancong, pejalan mandiri. Istilah flashpacker muncul ditengah konvergensi atau penyatuan antara mobilitas fisik traveler dengan perkembangan teknologi komunikasi digital dan internet (Paris, 2012; Germann \& Paris, 2015; Pitana \& Pitanatri, 2016) Teknologi 
digital memungkinkan flashpackers untuk mobile ke lebih banyak tempat dalam waktu singgah yang lebih singkat.

\section{Penutup}

Flashpacker adalah sub-bidang di nexus studi wisatawan yang muncul karena adanya evolusi dari wisatawan itu sendiri. Serangkaian proposisi inti telah diidentifikasi dan ini secara kolektif menjelaskan mengapa studi flashpacker dianggap penting, serta menghasilkan tujuan untuk pengembangannya.

Sampai saat ini literatur tentang flashpacker masih sangat minim sehingga pengembangkan studi ini secara menyeluruh masih sangat dibutuhkan. Salah satu tantangan utama adalah bahwa banyak disiplin ilmu dan bidang lain yang mengangkat fenomena ini nantinya akan berkontribusi terhadap banyak wacana dan topik penelitian yang menghubungkan flaspacker dan studi pariwisata dengan cara interdisipliner.

Sementara pemetaan ontologis lengkap dari studi flashpacker masih harus dikembangkan, ulasan dari artikel ini diharapkan telah mengidentifikasi konsepkonsep dasar untuk mengembangkan pengetahuan flashpacker. Setelah memahami apa itu flashpacker, maka selanjutnya dibutuhkan wawasan tentang bagaimana pengetahuan ini dikembangkan melalui berbagai metode penelitian. Untuk tujuan tersebut maka dibutuhkan diskusi lanjutan secara ontologis dan analisis secara sistematis dari semua literatur terkait, baik dari urnal penelitian dan dari praksis, sehingga klaim pengetahuan (termasuk semua konsep yang digunakan) data digunakan untuk menyusun dan membakukan terminologi flashpacker. Akhirnya penting untuk menyimpulkan dengan fokus flashpacker sebagai cara baru mempelajari jenis wisatawan. Saat ini tidak memang masih sangat immature, tetapi tidak bisa dihindari bahwa flashpacker akan menemukan tempat sendiri dalam disiplin inlu pariwisata. 


\section{Daftar Pustaka}

Bleach, S. and Schofield, B., 2004. Are you a flashpacker? Time to bust the budget and go backpacking in style. The Sunday Times, 31.

Bleach, S., \& Schofield, B. 2004. Time to go backpacking in style. The Times (London).

Bosangit, C., Hibbert, S., \& McCabe, S. 2015. "If I was going to die I should at least be having fun": Travel blogs, meaning and tourist experience. Annals of Tourism Research, 55, 1-14. https://doi.org/10.1016/j.annals.2015.08.001

Buhalis, D., \& Law, R. 2008. Progress in information technology and tourism management: 20 years on and 10 years after the Internet-The state of eTourism research. Tourism Management, 29(4), 609-623. https://doi.org/10.1016/j.tourman.2008.01.005

Butler, G., \& Hannam, K. 2014. Flashpacking and automobility. Current Issues in Tourism, 17(8), 739-752. https://doi.org/10.1080/13683500.2013.783793

Butler, Gareth, \& Hannam, K. 2014. Flashpacking and automobility. Current Issues in Tourism, 17(8), 739-752. https://doi.org/10.1080/13683500.2013.783793

Cave, J., Thyne, M., \& Ryan, C. 2007. Perceptions of backpacker accommodation facilities: A comparative study of Scotland and New Zealand. Backpacker Tourism: Concepts and Profiles.

Cochrane, J. 2005. The backpacker plus: Overlooked and underrated. Paper read.

Cohen, E. 1979. Rethinking the sociology of tourism. Annals of tourism research, 6(1), 18-35.

Crompton, J. L. 1979. Motivations for pleasure vacation. Annals of tourism research, 6(4), 408424.

Cheng, M. 2016. Sharing economy: A review and agenda for future research. International Journal of Hospitality Management, 57, 60-70. https://doi.org/10.1016/j.ijhm.2016.06.003

Dayour, F., Kimbu, A. N., \& Park, S. 2017. Backpackers: The need for reconceptualisation. Annals of Tourism Research. https://doi.org/10.1016/j.annals.2017.06.004

Desforges, L. 2000. Traveling the world: Identity and Travel Biography. Annals of Tourism Research, 27(4), 926-945. https://doi.org/10.1016/S0160-7383(99)00125-5

Dictionary.com. (n.d.). Flashpacker I Definition of Flashpacker at Dictionary.com. Retrieved December 7, 2019, from https://www.dictionary.com/browse/flashpacker?s=t

Flashpack.com. (n.d.). Are you a Flashpacker? I Flash Pack. Retrieved December 7, 2019, from https://www.flashpack.com/insights/2019/04/15/are-you-a-flashpacker/

Flognfeldt, T. 2005. The tourist route system - Models of travelling patterns. BELGEO, (1-2), 35-58. https://doi.org/10.4000/belgeo.12406 
Germann Molz, J., \& Paris, C. M. 2015. The Social Affordances of Flashpacking: Exploring the Mobility Nexus of Travel and Communication. Mobilities, 10(2), 173-192. https://doi.org/10.1080/17450101.2013.848605

Getz, D. 2008. Event tourism: Definition, evolution, and research. Tourism Management. https://doi.org/10.1016/j.tourman.2007.07.017

Getz, D., \& Page, S. J. 2014, January 15. Progress and prospects for event tourism research. Tourism Management. Elsevier Ltd. https://doi.org/10.1016/j.tourman.2015.03.007

Gregory, R. (n.d.). A Brief History of the Hippie Trail. Retrieved December 4, 2019, from https://www.richardgregory.org.uk/history/hippie-trail.htm

Gretzel, U., Werthner, H., Koo, C., \& Lamsfus, C. 2015. Conceptual foundations for understanding smart tourism ecosystems. Computers in Human Behavior, 50, 558-563. https://doi.org/10.1016/j.chb.2015.03.043

Hannam, K., \& Diekmann, A. 2010. Beyond backpacker tourism: Mobilities and experiences. Beyond Backpacker Tourism: Mobilities and Experiences.

Hing, N., Mccabe, V., Lewis, P., \& Leiper, N. 1998. Hospitality trends in the Asia-Pacific: A discussion of five key sectors. International Journal of Contemporary Hospitality Management, 10(7), 264-271. https://doi.org/10.1108/09596119810240852

Loker-Murphy, L., \& Pearce, P. L. 1995. Young budget travelers: Backpackers in Australia. Annals of Tourism Research, 22(4), 819-843. https://doi.org/10.1016/0160-7383(95)00026-0

Luo, X., Huang, S. S., \& Brown, G. 2015. Backpacking in China: A Netnographic Analysis of Donkey Friends' Travel Behaviour. Journal of China Tourism Research, 11(1), 67-84. https://doi.org/10.1080/19388160.2014.908757

Ly, M. B. 2018. An application of Butler's (1980) Tourist Area Life Cycle to Saly (Senegal). International Journal for Innovation Education and Research www.ijier.net. Retrieved from http://ijier.net/ijier/article/view/919

Maoz, D. 2006. Erikson on the Tour. Tourism Recreation Research, 31(3), 55-63. https://doi.org/10.1080/02508281.2006.11081505

Maoz, Darya. 2006. The mutual gaze. Annals of Tourism Research, 33(1), 221-239. https://doi.org/10.1016/j.annals.2005.10.010

Maoz, Darya. 2007. Backpackers' motivations the role of culture and nationality. Annals of Tourism Research, 34(1), 122-140. https://doi.org/10.1016/j.annals.2006.07.008

Minghetti, V., \& Buhalis, D. 2010. Digital divide in tourism. Journal of Travel Research, 49(3), 267-281. https://doi.org/10.1177/0047287509346843

Mistilis, N., Buhalis, D., \& Gretzel, U. 2014. Future eDestination Marketing: Perspective of an Australian Tourism Stakeholder Network. Journal of Travel Research, 53(6), 778-790. https://doi.org/10.1177/0047287514522874 
Morrison, A. M., Pearce, P. L., Moscardo, G., Nadkarni, N., \& O'Leary, J. T. 1996. Specialist accommodation: Definition, markets served, and roles in tourism development. Journal of Travel Research, 35(1), 18-26. https://doi.org/10.1177/004728759603500104

Murphy, L. L. 1997. Backpackers in australia: A motivation-based segmentation study. Journal of Travel and Tourism Marketing, 5(4), 23-45. https://doi.org/10.1300/J073v05n04_02

Noy, C. 2004. This trip really changed me: Backpackers' narratives of self-change. Annals of Tourism Research, 31(1), 78-102. https://doi.org/10.1016/j.annals.2003.08.004

Noy, C. 2005. Israeli backpackers: Narrative, interpersonal communication, and social construction. Israeli Backpackers: From Tourism to Rite of Passage.

Noy, Chaim. 2004. This trip really changed me: Backpackers' narratives of self-change. Annals of Tourism Research, 31(1), 78-102. https://doi.org/10.1016/j.annals.2003.08.004

O' Regan, M. 2018. Backpacking's future and its drifter past. Journal of Tourism Futures, 4(3), 193-204. https://doi.org/10.1108/JTF-04-2018-0019

O'Reilly, C. C. 2006a. From drifter to gap year tourist. Mainstreaming Backpacker Travel. Annals of Tourism Research, 33(4), 998-1017. https://doi.org/10.1016/j.annals.2006.04.002

O'Reilly, C. C. 2006b. From drifter to gap year tourist. Mainstreaming Backpacker Travel. Annals of Tourism Research, 33(4), 998-1017. https://doi.org/10.1016/j.annals.2006.04.002

Page, S. J. 2009. Tourism Management (3rd Editio). Burlington, USA: Elsevier.

Paris, C.M. 2012. FLASHPACKERS: An Emerging Sub-Culture? Annals of Tourism Research, 39(2), 1094-1115. https://doi.org/10.1016/j.annals.2011.12.001

Paris, Cody Morris. 2012. FLASHPACKERS: An Emerging Sub-Culture? Annals of Tourism Research, 39(2), 1094-1115. https://doi.org/10.1016/j.annals.2011.12.001

Pearce, P.L. 2006. Backpacking and Backpackers-A Fresh Look. Tourism Recreation Research, 31(3), 5-10. https://doi.org/10.1080/02508281.2006.11081501

Pearce, P.L. 2012. Relationships and the tourism experience: Challenges for quality-of-life assessments. Handbook of Tourism and Quality-of-Life Research: Enhancing the Lives of Tourists and Residents of Host Communities. https://doi.org/10.1007/978-94-007-2288-0_2

Pearce, P.L., \& Maoz, D. 2008. Novel insights into the identity changes among backpackers. Tourism, Culture and Communication, 8(1), 27-43. https://doi.org/10.3727/109830408783900325

Pearce, Philip L, Murphy, L., \& Brymer, E. 2009. Evolution of the Backpacker Market and the Potential for Australian Tourism. Sustainable Tourism Cooperative Research Centre's (STCRC's).

Pitanatri, P. D. S., \& Pitana, I. G. 2019. What Do We Know About Flashpacker? A Review. In The 3rd Bali International Tourism Conference (pp. 23-33). 
Pitana, I. G., \& Pitanatri, P.D.S. 2016. Digital marketing in tourism: the more global, the more personal. In International Tourism Conference: Promoting Cultural and Heritage Tourism. Udayana University, Bali (pp. 1-3).

Pitaya, P., Baiquni, M., Marsono, M., \& Nopirin, N. 2019. Paradigma Historis Backpacking Travel Sebagai Perjalanan Wisata. Jurnal Pariwisata Terapan, 3(1), 34. https://doi.org/10.22146/jpt.49274

Plog, S. C. 1974. Why Destination Areas Rise and Fall in Popularity. Cornell Hotel and Restaurant Administration Quarterly, 14(4), 55-58. https://doi.org/10.1177/001088047401400409

Prebensen, N. K. 2017. The mediating effect of real life encounters in co-writing tourism books. Tourism Management, 62, 1-9. https://doi.org/10.1016/j.tourman.2017.03.008

Reichel, A., Fuchs, G., \& Uriely, N. 2009. ISRAELI BACKPACKERS. The Role of Destination Choice. Annals of Tourism Research, 36(2), 222-246. https://doi.org/10.1016/j.annals.2008.11.002

Richards, G. 2015. The new global nomads: Youth travel in a globalizing world. Tourism Recreation Research, 40(3), 340-352. https://doi.org/10.1080/02508281.2015.1075724

Richards, Greg., \& Wilson, J. 2004. The global nomad: backpacker travel in theory and practice. Channel View Publications.

Richards, Greg. 2011, October. Creativity and tourism. The state of the art. Annals of Tourism Research. https://doi.org/10.1016/j.annals.2011.07.008

Rosenberg, H. 2019. The "flashpacker" and the "unplugger": Cell phone (dis)connection and the backpacking experience. Mobile Media and Communication, 7(1), 111-130. https://doi.org/10.1177/2050157918777778

Ryan, C., Trauer, B., Kave, J., Sharma, A., \& Sharma, S. 2003. Backpackers - What is the Peak Experience? Tourism Recreation Research, 28(3), 93-98. https://doi.org/10.1080/02508281.2003.11081421

Sroypetch, S. 2016. The mutual gaze: Host and guest perceptions of socio-cultural impacts of backpacker tourism: A case study of the Yasawa Islands, Fiji. Journal of Marine and Island Cultures. https://doi.org/10.1016/j.imic.2016.09.004

The History of Backpacking | Where did it all begin? (n.d.). Retrieved October 8, 2019, from https://nomadsworld.com/history-of-backpacking/

The tourist and visitor experience. 2013. The Routledge Handbook of Cultural Tourism. https://doi.org/10.4324/9780203120958

UNESCO. (n.d.). About the Silk Road I SILK ROADS. Retrieved December 5, 2019, from https://en.unesco.org/silkroad/about-silk-road 
Uriely, N. 2009. Deconstructing tourist typologies: The case of backpacking. International Journal of Culture, Tourism and Hospitality Research, 3(4), 306-312. https://doi.org/10.1108/17506180910994523

Uriely, N., Yonay, Y., \& Simchai, D. 2002. Backpacking experiences: A type and form analysis. Annals of Tourism Research, 29(2), 520-538. https://doi.org/10.1016/S0160-7383(01)00075-5

Wang, D., Xiang, Z., \& Fesenmaier, D. R. 2016. Smartphone Use in Everyday Life and Travel. Journal of Travel Research, 55(1), 52-63. https://doi.org/10.1177/0047287514535847

Warwick Ball (2016), Rome in the East: Transformation of an Empire, 2nd edition, London \& New York: Routledge, ISBN 978-0-415-72078-6, p. 155.

Xiang, Z., Magnini, V. P., \& Fesenmaier, D. R. 2015. Information technology and consumer behavior in travel and tourism: Insights from travel planning using the internet. Journal of Retailing and Consumer Services, 22, 244-249. https://doi.org/10.1016/j.jretconser.2014.08.005

Xiang, Z., Wang, D., O'Leary, J. T., \& Fesenmaier, D. R. 2015. Adapting to the Internet: Trends in Travelers' Use of the Web for Trip Planning. Journal of Travel Research, 54(4), 511-527. https://doi.org/10.1177/0047287514522883

Yeoman, I. 2013. A futurist's thoughts on consumer trends shaping future festivals and events. International Journal of Event and Festival Management, 4(3), 249-260. https://doi.org/10.1108/IJEFM-06-2013-0017

Zhang, J., Tucker, H., Morrison, A. M., \& Wu, B. 2017. Becoming a backpacker in China: A grounded theory approach to identity construction of backpackers. Annals of Tourism Research. https://doi.org/10.1016/j.annals.2017.03.004

\section{Profil Penulis}

Putu Diah Sastri Pitanatri adalah dosen Politeknik Pariwisata Bali. Selain aktif mengajar, Diah sangat senang menulis. Saat ini sudah ada dua buku yang diterbitkan secara internal bersama rekan pengajar di Politeknik Pariwisata Bali, yaitu Pengantar Pemasaran (2014) dan Pemasaran Hospitaliti (2015). Beberapa tulisannya juga sudah diterbitkan pada prosiding internasional dan jurnal nasional. Selain kuliner Bali, passion menulisnya ada pada cakupan heritage, cultural tourism, local entrepreneurship dan marketing. 